\title{
General Recyclable Redox-Metallothermic Reaction Route to Hierarchically Porous Carbon/Metal Composites
}

\footnotetext{
Kyung Joo Lee, ${ }^{\dagger, \downarrow}$ Sinho Choi, ${ }^{\dagger, \S}$ Soojin Park ${ }^{*}, \S$ and Hoi Ri Moon*,

$\$$ Department of Chemistry, School of Natural Science, Ulsan National Institute of Science and Technology (UNIST), Ulsan 44919, Republic of Korea

$\S$ Department of Energy Engineering, School of Energy and Chemical Engineering, Ulsan National Institute of Science and Technology (UNIST), Ulsan 44919, Republic of Korea

$\dagger$ These authors contributed equally.
}

* e-mail:spark@unist.ac.kr; hoirimoon@unist.ac.kr 
Table S1. Summary of experiment conditions with different molar ratio of $\mathrm{Zn}^{2+}$ to $\mathrm{Ge}^{4+}$ and elemental compositions of its resultant materials.

\begin{tabular}{|c|c|c|c|c|c|c|c|c|c|c|}
\hline \multirow{2}{*}{$\begin{array}{l}\text { Sample } \\
\text { Name }^{\mathrm{a}}\end{array}$} & \multirow{2}{*}{$\begin{array}{c}\text { Actual weight } \\
\mathrm{Zn-MOF} \mathrm{:} \mathrm{GeO}_{2}\end{array}$} & \multirow{2}{*}{$\begin{array}{l}\text { Molar ratio } \\
\mathrm{Zn}^{2+} / \mathrm{Ge}^{4+}\end{array}$} & \multirow[t]{2}{*}{ Thermolysis condition } & \multirow{2}{*}{$\begin{array}{c}\text { Reducing } \\
\text { efficiency of } \\
Z^{\mathbf{b}}\end{array}$} & \multicolumn{5}{|c|}{$\begin{array}{l}\text { Elemental composition of the } \\
\text { resultant materials (wt } \% \text { ) }\end{array}$} & \multirow[t]{2}{*}{ Yield $(\mathrm{g})$} \\
\hline & & & & & $C^{c}$ & $\mathrm{H}^{\mathrm{c}}$ & $\mathrm{N}^{\mathrm{c}}$ & $\mathrm{Ge}^{\mathrm{d}}$ & $\mathrm{Zn}^{\mathrm{d}}$ & \\
\hline $\mathrm{Ge} / \mathrm{HPC}-2$ & $0.78 \mathrm{~g}: 0.1 \mathrm{~g}$ & 2 & $\begin{array}{c}10{ }^{\circ} \mathrm{C} / \mathrm{min} \text { to } 800{ }^{\circ} \mathrm{C} \\
800{ }^{\circ} \mathrm{C} \text { for } 6 \mathrm{~h}\end{array}$ & $100 \%$ & 60.6 & 1.1 & 4.3 & 33.5 & 0.5 & 0.20 \\
\hline Ge/HPC-0.6 & $0.24 \mathrm{~g}: 0.1 \mathrm{~g}$ & 0.6 & $\begin{array}{c}10{ }^{\circ} \mathrm{C} / \mathrm{min} \text { to } 800{ }^{\circ} \mathrm{C} \\
800{ }^{\circ} \mathrm{C} \text { for } 6 \mathrm{~h}\end{array}$ & $333 \%$ & 29.6 & 0.4 & 1.8 & 68.1 & 0.08 & 0.07 \\
\hline Ge/HPC-0.3 & $0.12 \mathrm{~g}: 0.1 \mathrm{~g}$ & 0.3 & $\begin{array}{c}10{ }^{\circ} \mathrm{C} / \mathrm{min} \text { to } 800{ }^{\circ} \mathrm{C} \\
800{ }^{\circ} \mathrm{C} \text { for } 6 \mathrm{~h}\end{array}$ & $667 \%$ & 11.7 & 0.2 & 0.9 & 87.2 & 0.05 & 0.02 \\
\hline
\end{tabular}

${ }^{a} \mathrm{Ge} / \mathrm{HPC}-\mathrm{X}$, in which $\mathrm{X}$ denotes $\mathrm{Zn}^{2+} / \mathrm{Ge}^{4+}$ mole ratio in the reactants

${ }^{\mathrm{b}}$ Reducing efficiency of $\mathrm{Zn}$ was calculated as follows.

Reducing efficiency of $\mathrm{Zn}=\frac{\text { mole of oxygen atoms in } \mathrm{Ge} \mathrm{O}_{2}}{\text { mole of } \mathrm{Zn} \text { atoms in the } \mathrm{Zn}-\mathrm{MOF}} \times 100(\%)$

${ }^{c}$ Measured values determined by elemental combustion analysis (EA)

${ }^{\mathrm{d}}$ Measured values determined by inductively coupled plasma (ICP) 
Table S2. Summary of $\mathrm{N}_{2}$ sorption isotherm of Ge/HPC series.

\begin{tabular}{|c|c|c|c|c|}
\hline \multirow{2}{*}{ Sample Name } & \multirow{2}{*}{$\begin{array}{c}\mathrm{S}_{\mathrm{BET}}^{\mathrm{a}} \\
\left(\mathrm{m}^{2} \mathrm{~g}^{-1}\right)\end{array}$} & \multirow{2}{*}{ 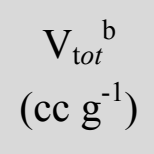 } & \multicolumn{2}{|c|}{$D_{\mathrm{NLDFT}}^{\mathrm{c}}(\mathrm{nm})$} \\
\hline & & & micro & meso \\
\hline Ge/HPC-2 & 292 & 0.36 & $0.6,1.3$ & $2 \sim 10$ \\
\hline Ge/HPC-1 & 140 & 0.10 & 0.9 & $2 \sim 5$ \\
\hline Ge/HPC-0.6 & 95 & 0.07 & 0.5 & $2 \sim 6$ \\
\hline Ge/HPC-0.3 & 59 & 0.04 & 0.6 & $2 \sim 5$ \\
\hline
\end{tabular}

a The specific surface area $\left(\mathrm{S}_{\mathrm{BET}}\right)$ was calculated by Brunauer-Emmet-Teller (BET) method.

${ }^{\mathrm{b}} \mathrm{V}_{\text {tot }}$ represented the total pore volume at $P / P_{0}=0.99$.

${ }^{\mathrm{c}}$ Pore size distribution calculated with a NLDFT method. 
Table S3. Details of experiment conditions about reduction of other metal oxides.

\begin{tabular}{|c|c|c|c|c|}
\hline $\begin{array}{l}\text { Metal oxide } \\
\qquad\left(\mathrm{MO}_{\mathrm{x}}\right)\end{array}$ & $\begin{array}{l}\text { Actual weight } \\
\mathrm{Zn}-\mathrm{MOF}: \mathrm{MO}_{\mathrm{x}}\end{array}$ & $\begin{array}{l}\text { Molar ratio } \\
\mathrm{Zn}^{2+} / \mathrm{MO}_{\mathrm{x}}\end{array}$ & Thermolysis condition & $\begin{array}{c}\text { Reducing } \\
\text { efficiency of } \\
\mathrm{Zn}^{\mathrm{a}}\end{array}$ \\
\hline $\mathrm{Bi}_{2} \mathrm{O}_{3}$ & $0.09 \mathrm{~g}: 0.1 \mathrm{~g}$ & 1 & $\begin{array}{c}10{ }^{\circ} \mathrm{C} / \mathrm{min} \text { to } 800{ }^{\circ} \mathrm{C} \\
800{ }^{\circ} \mathrm{C} \text { for } 6 \mathrm{~h}\end{array}$ & $300 \%$ \\
\hline $\mathrm{In}_{2} \mathrm{O}_{3}$ & $0.15 \mathrm{~g}: 0.1 \mathrm{~g}$ & 1 & $\begin{array}{c}10{ }^{\circ} \mathrm{C} / \mathrm{min} \text { to } 800{ }^{\circ} \mathrm{C} \\
800{ }^{\circ} \mathrm{C} \text { for } 6 \mathrm{~h}\end{array}$ & $300 \%$ \\
\hline $\mathrm{SnO}$ & $0.09 \mathrm{~g}: 0.1 \mathrm{~g}$ & 0.3 & $\begin{array}{c}10^{\circ} \mathrm{C} / \mathrm{min} \text { to } 800{ }^{\circ} \mathrm{C} \\
800{ }^{\circ} \mathrm{C} \text { for } 6 \mathrm{~h}\end{array}$ & $300 \%$ \\
\hline
\end{tabular}

${ }^{a}$ Reducing efficiency of $\mathrm{Zn}$ was calculated as follows.

Reducing efficiency of $\mathrm{Zn}=\frac{\text { mole of axygen atoms in } M O_{x}}{\text { mole of } Z n \text { atoms in the } \mathrm{Zn}-\mathrm{MOF}} \times 100(\%)$ 
(a)

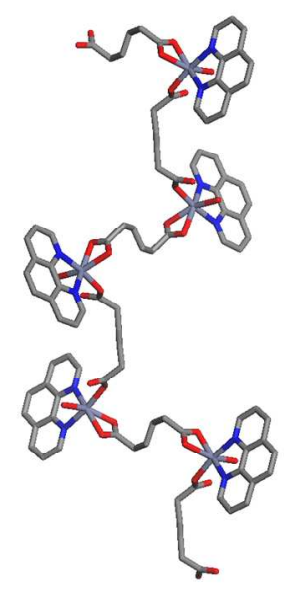

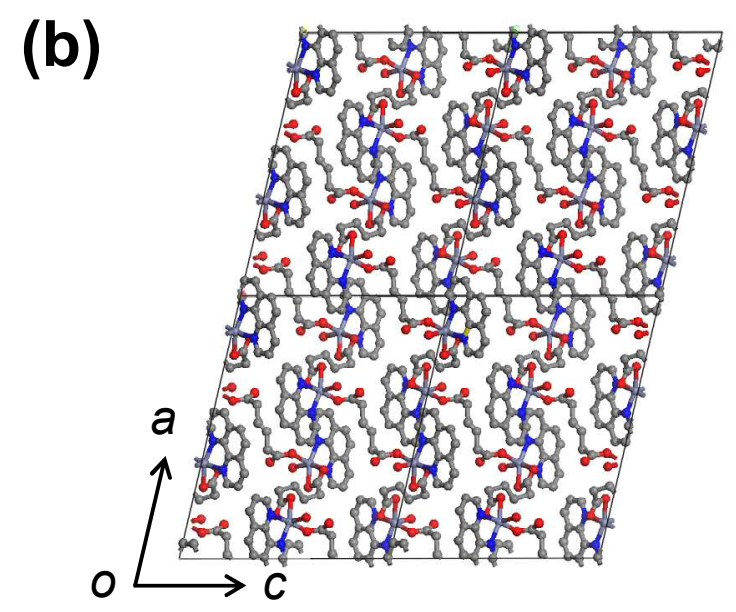

(b)

Figure S1. X-ray single crystal structures of a Zn-based MOF, [Zn(adipate)(phen) $\left(\mathrm{H}_{2} \mathrm{O}\right)$ ] for (a) its 1-D chain and (b) ac plane.

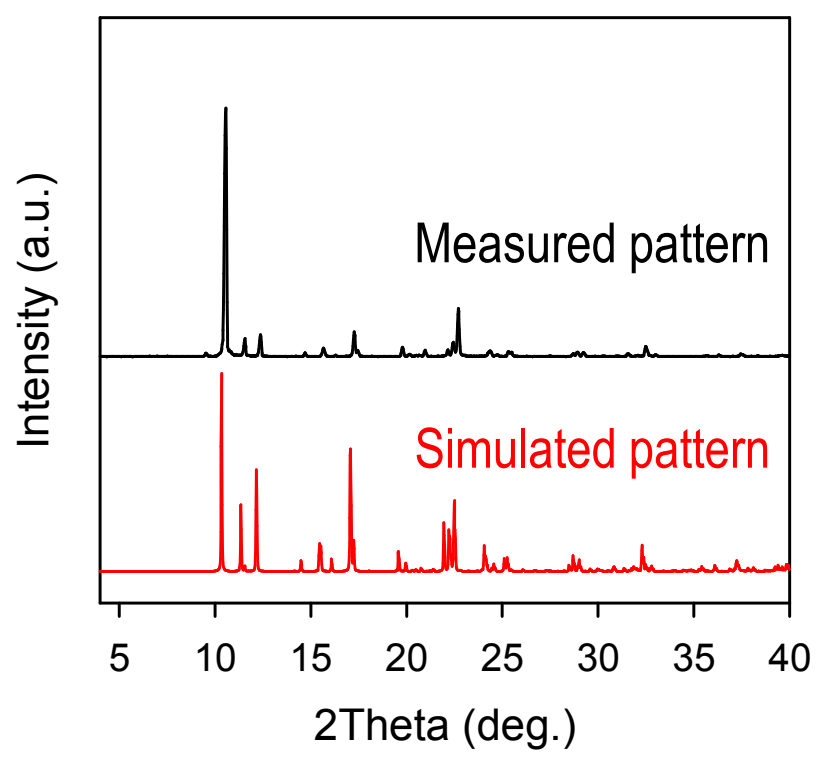

Figure S2. XRPD results of simulated pattern (red) and measured pattern (black) of assynthesized [Zn(adipate) $($ phen $\left.)\left(\mathrm{H}_{2} \mathrm{O}\right)\right]$. 


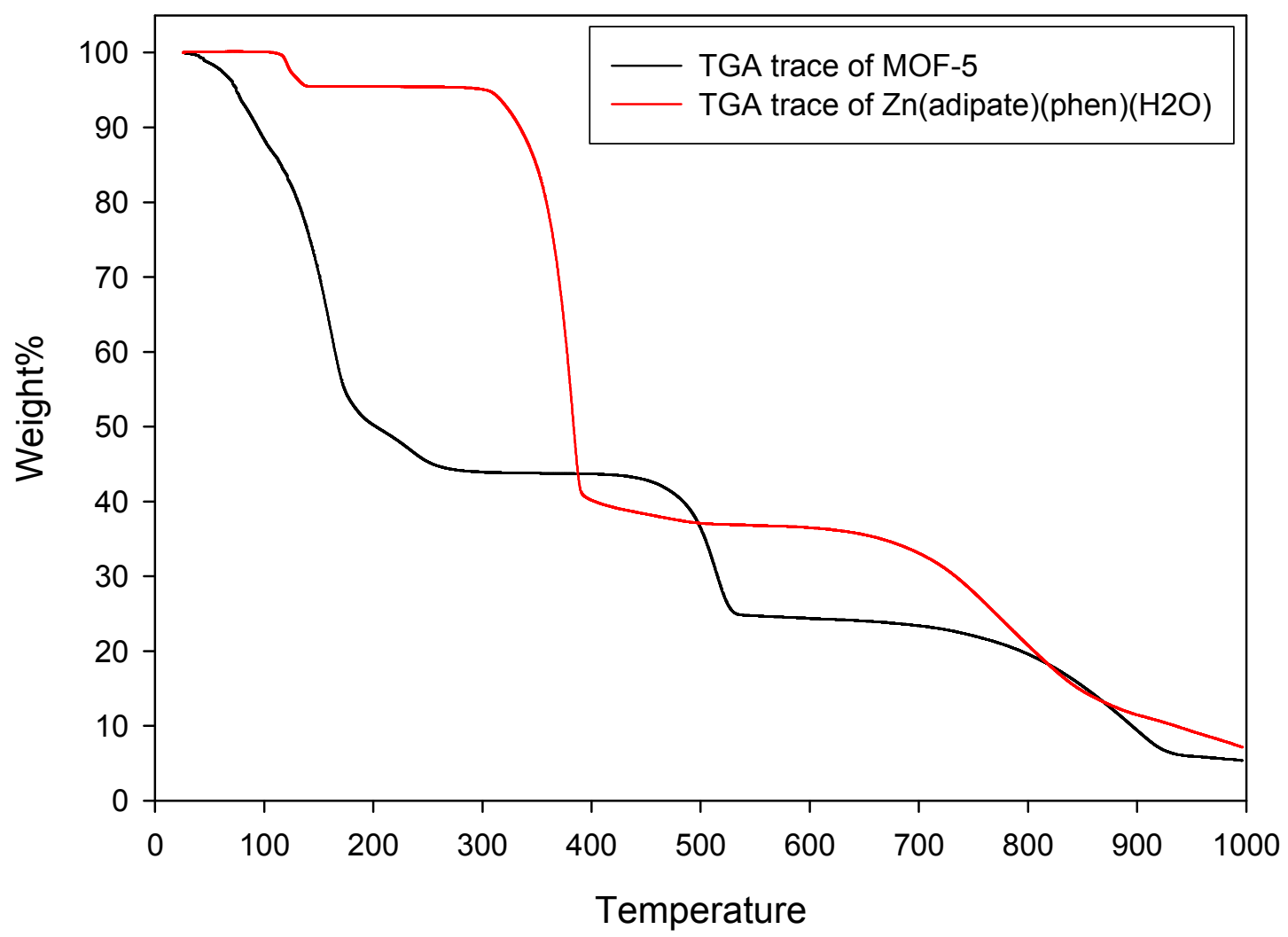

Figure S3. Comparison of TGA traces of $\left[\mathrm{Zn}(\right.$ adipate $\left.)(\mathrm{phen})\left(\mathrm{H}_{2} \mathrm{O}\right)\right]$ (red) and MOF-5 (black). 


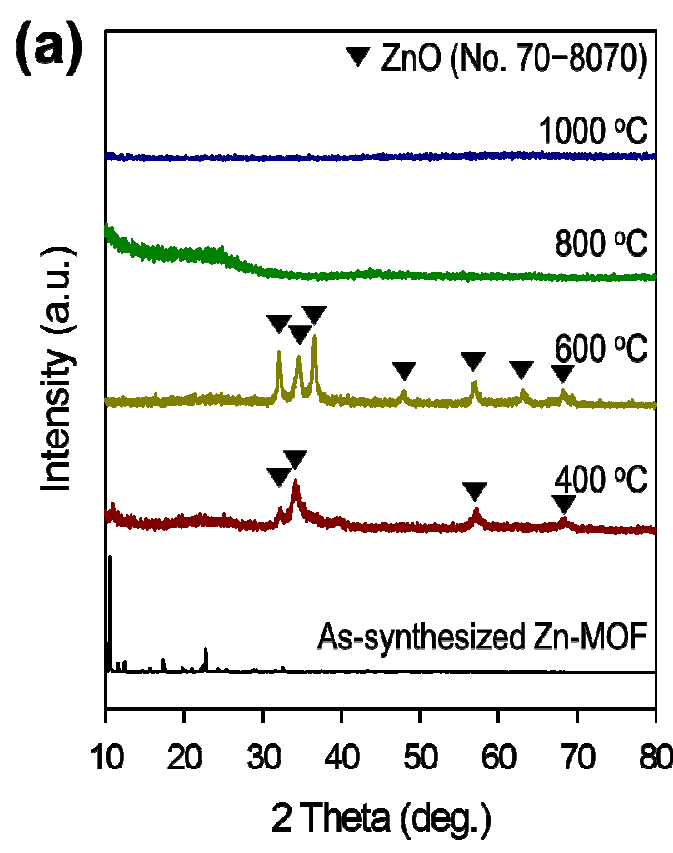

(b)
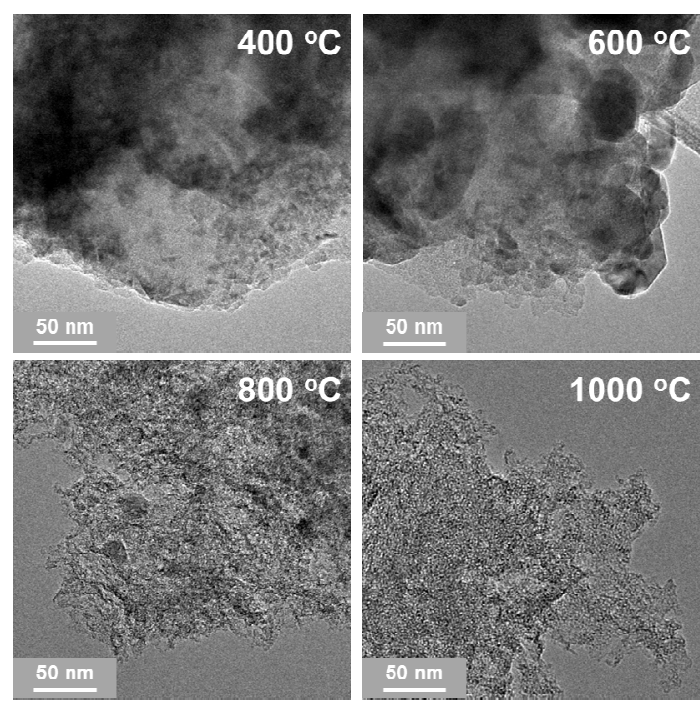

Figure S4. Thermal conversion of $\left[\mathrm{Zn}(\right.$ adipate $\left.)(\mathrm{phen})\left(\mathrm{H}_{2} \mathrm{O}\right)\right]$. (a) Variable temperature XRPD patterns of a Zn-MOF. (b) TEM images after heat treatment of a Zn-MOF from $400{ }^{\circ} \mathrm{C}$ to $1000{ }^{\circ} \mathrm{C}$ with $200{ }^{\circ} \mathrm{C}$ increments. 
(a)

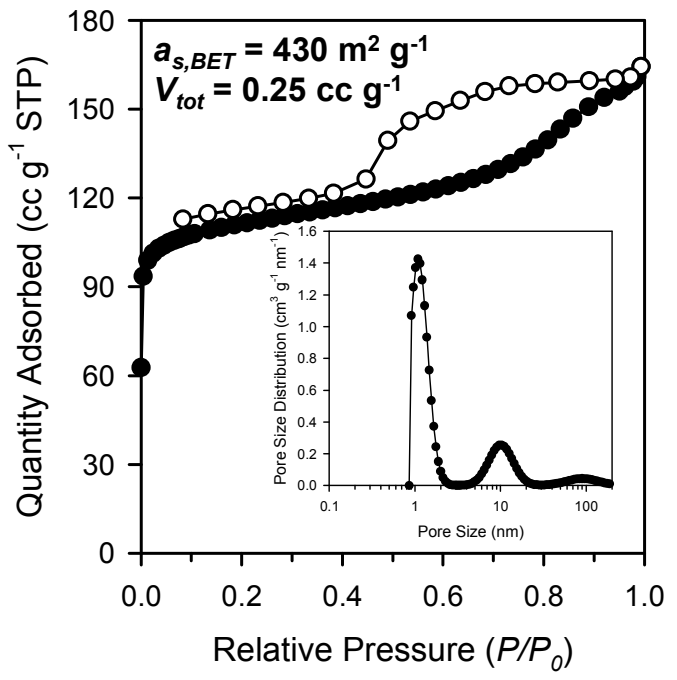

(b)

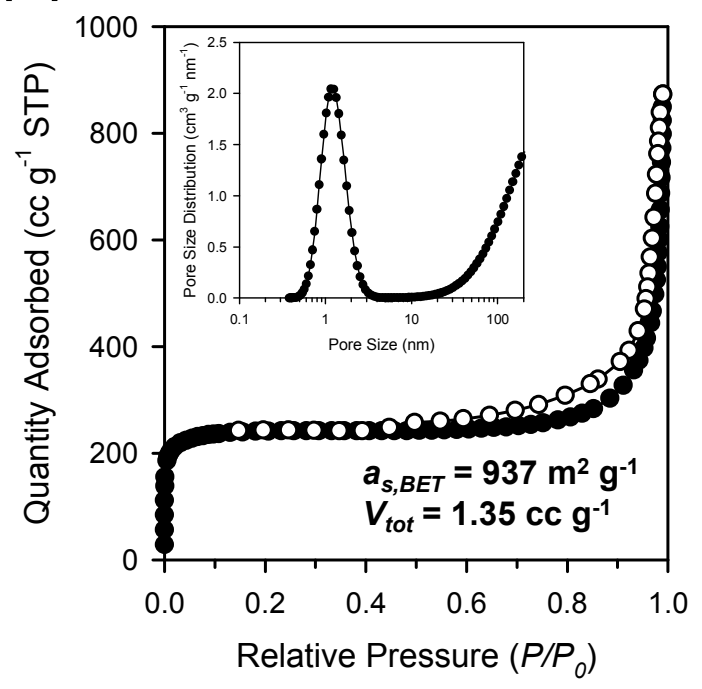

Figure S5. $\mathrm{N}_{2}$ sorption isotherms and NLDFT pore size distribution curves (inset) of the material converted from (a) $\left[\mathrm{Zn}(\right.$ adipate $)($ phen $\left.)\left(\mathrm{H}_{2} \mathrm{O}\right)\right]$, and (b) MOF-5. 

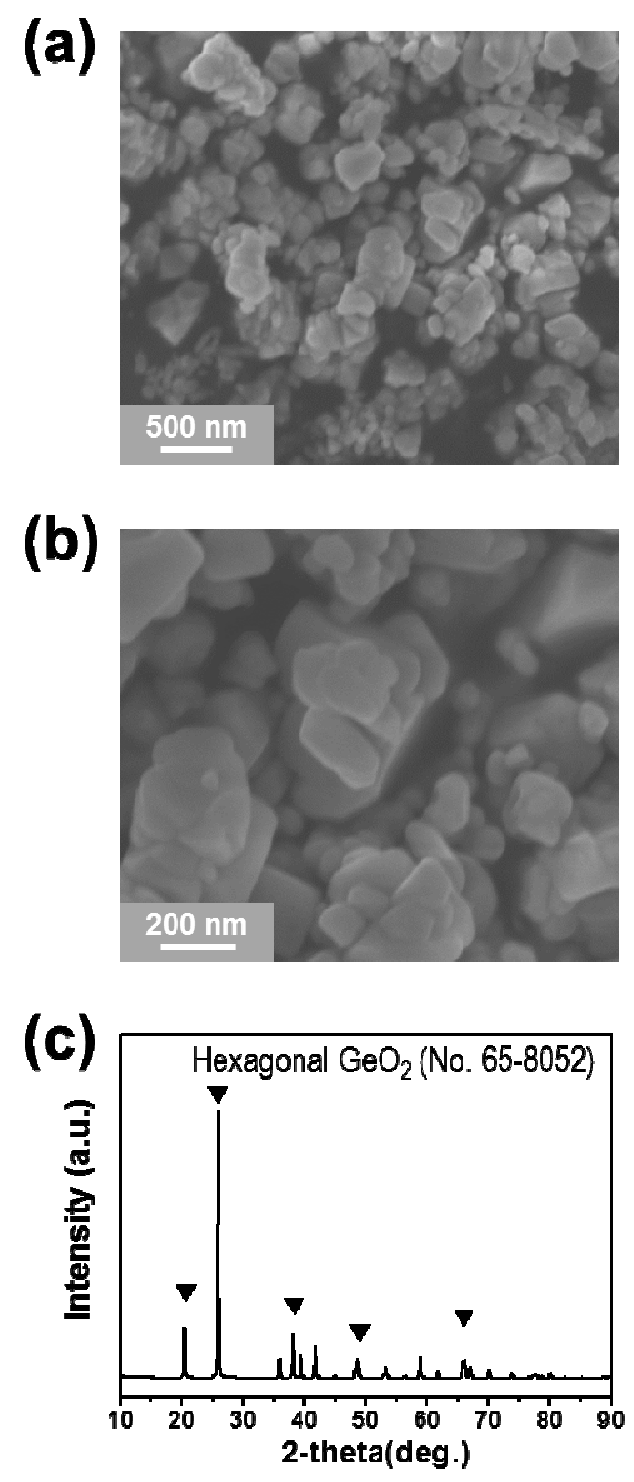

Figure S6. Characterization of commercially available bare $\mathrm{GeO}_{2}$. (a) SEM image of $\mathrm{GeO}_{2}$ powder. (b) High-magnification SEM image of (a). (c) XRPD pattern of crystalline $\mathrm{GeO}_{2}$. 


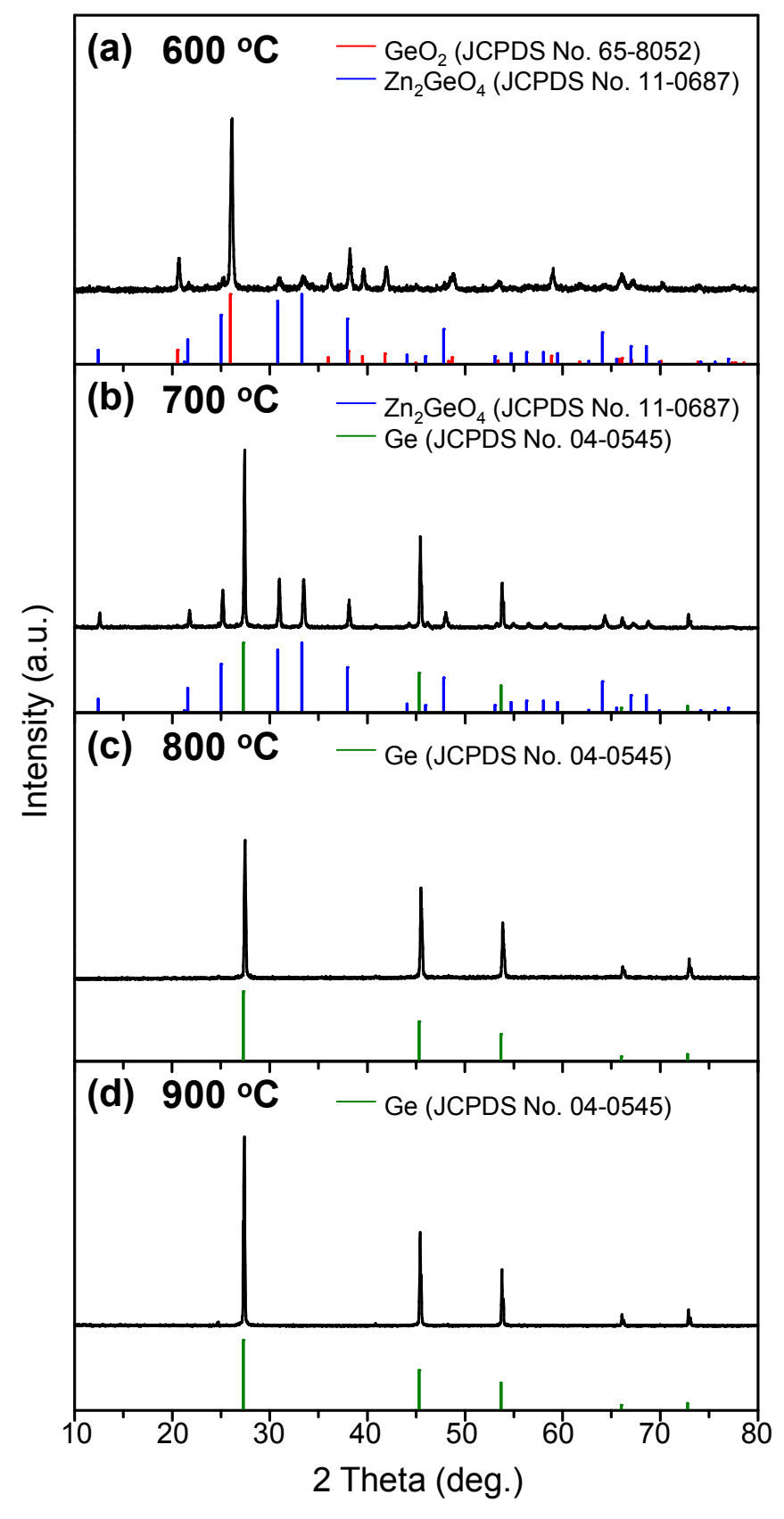

Figure S7. XRPD patterns after thermolysis for a mixture of $\mathrm{GeO}_{2}$ and a $\mathrm{Zn}-\mathrm{MOF}$ with fixed molar ratio at various temperature for $6 \mathrm{~h}$. (a) $600{ }^{\circ} \mathrm{C}$, (b) $700{ }^{\circ} \mathrm{C}$, (c) $800{ }^{\circ} \mathrm{C}$, and (d) $900{ }^{\circ} \mathrm{C}$. 


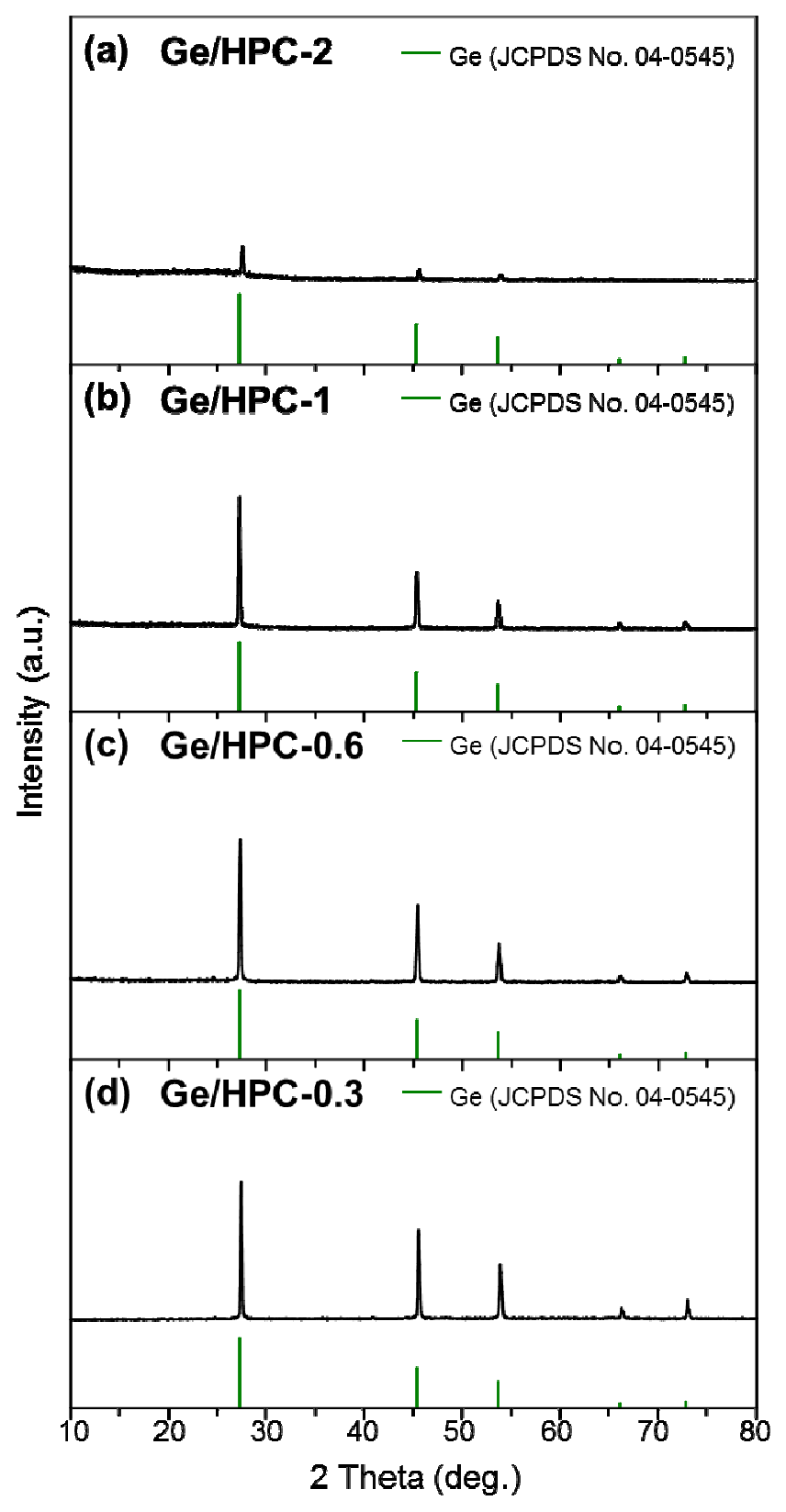

Figure S8. XRPD patterns of Ge/HPC series after heat treatment at $800{ }^{\circ} \mathrm{C}$ for $6 \mathrm{~h}$. (a) Ge/HPC-2. (b) Ge/HPC-1. (c) Ge/HPC-0.6. (d) Ge/HPC-0.3. 

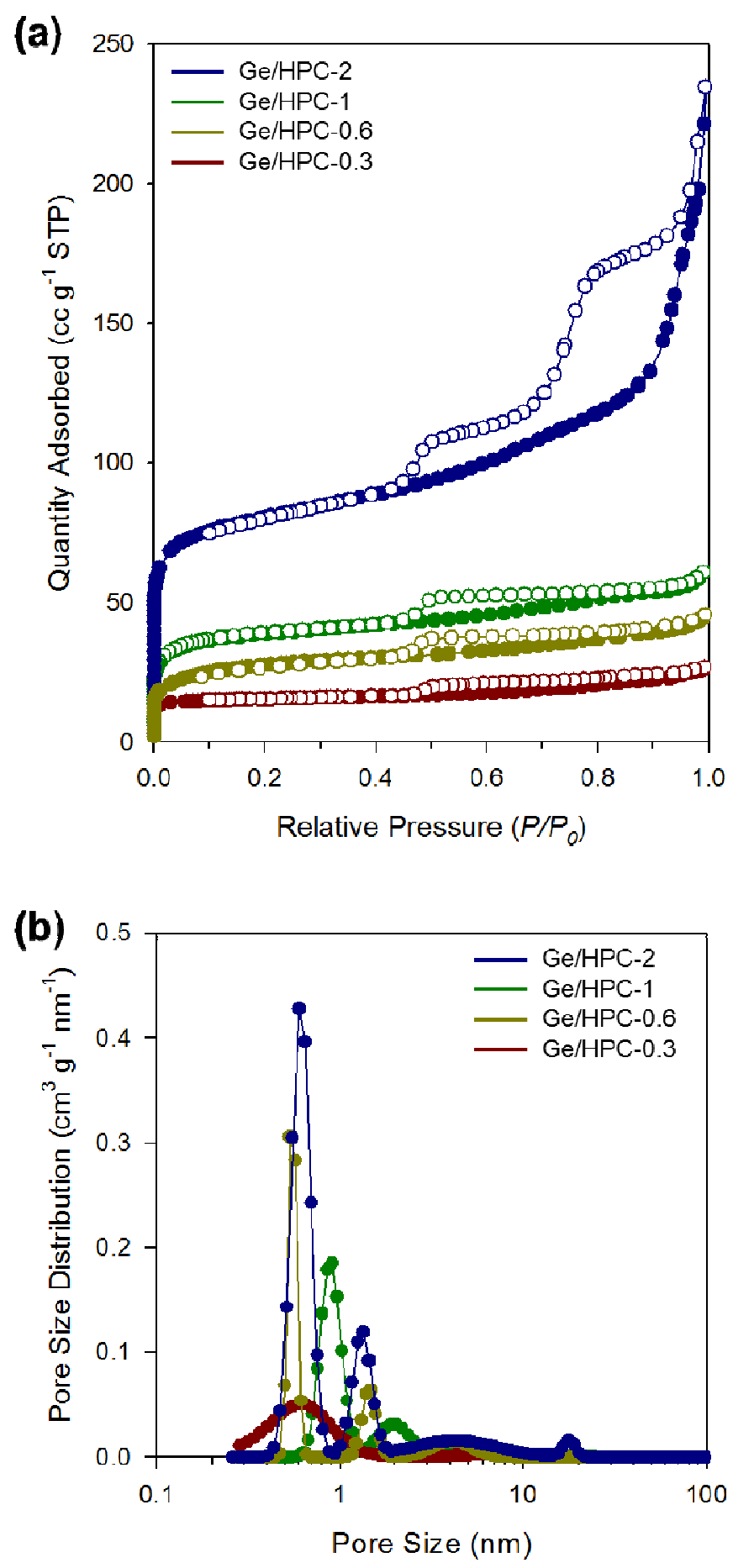

Figure S9. (a) $\mathrm{N}_{2}$ sorption isotherms and (b) NLDFT pore size distribution of Ge/HPC series. 


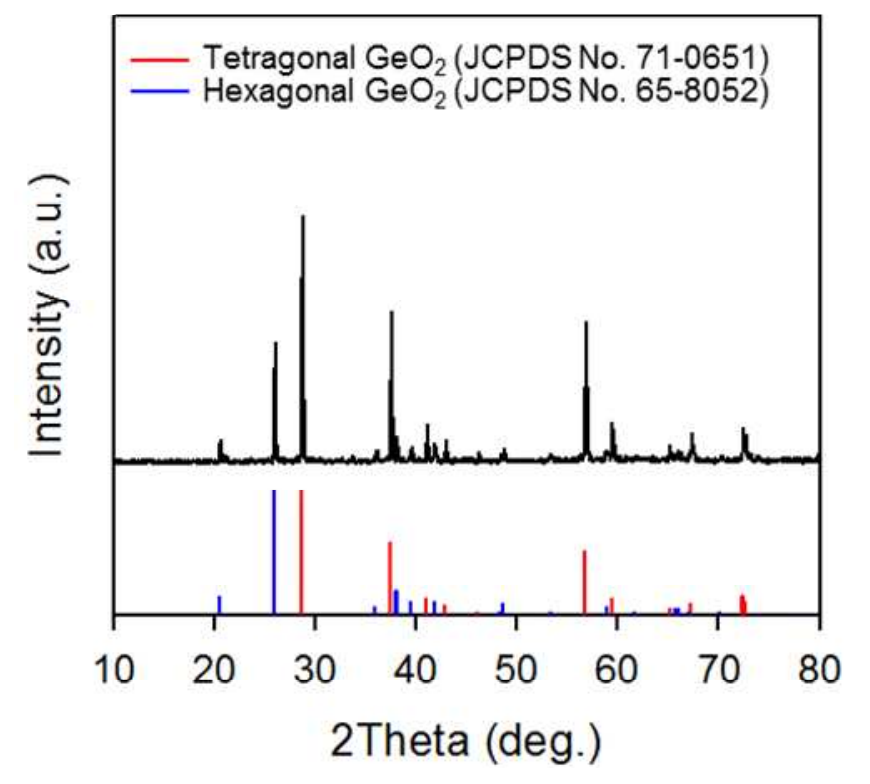

Figure S10. XRPD pattern after heat treatment for a mixture of organic ligands and $\mathrm{GeO}_{2}$ at $800{ }^{\circ} \mathrm{C}$ for $6 \mathrm{~h}$ 

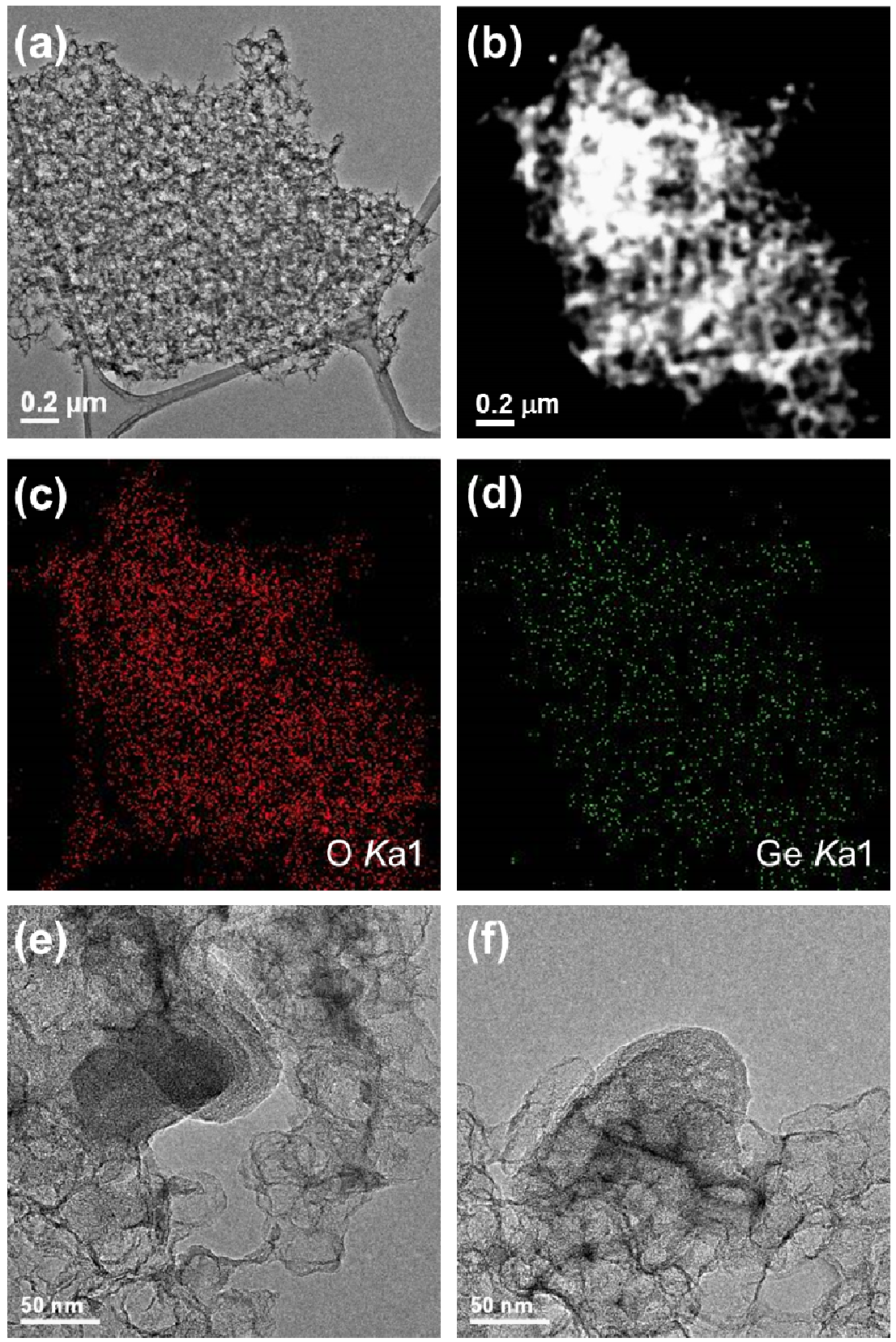

Figure S11. TEM images with various magnifications and EDS mapping of Ge/HPC-1. 
(a)

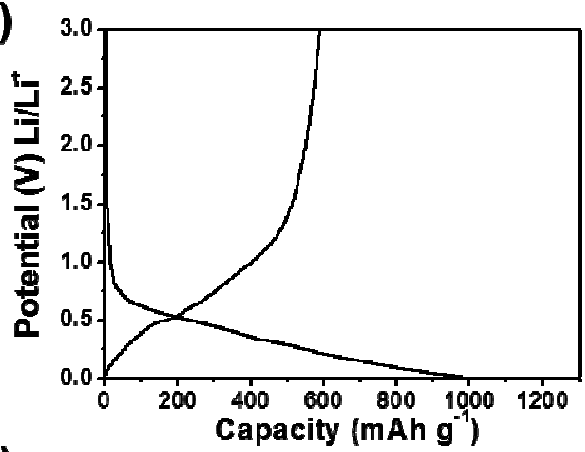

(b)

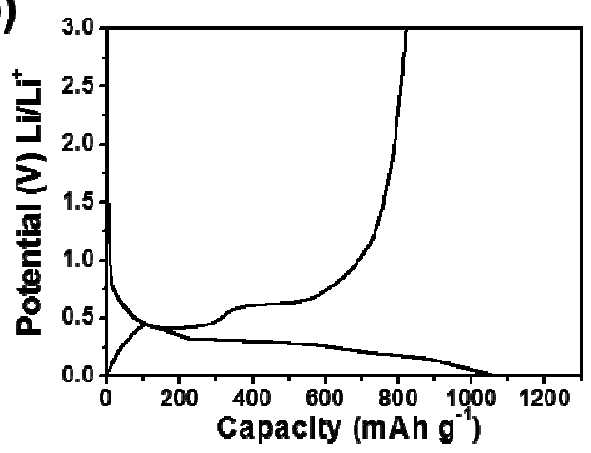

(c)

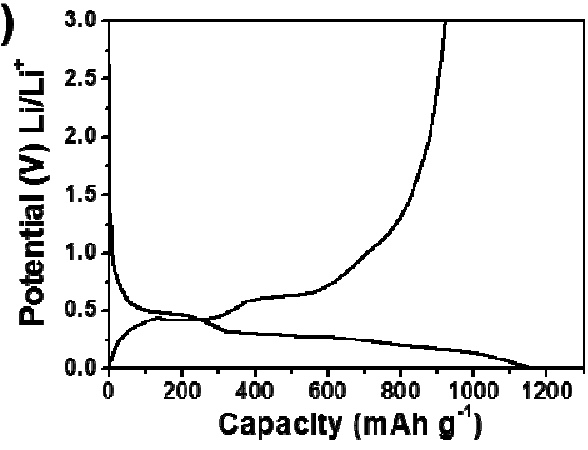

(d)

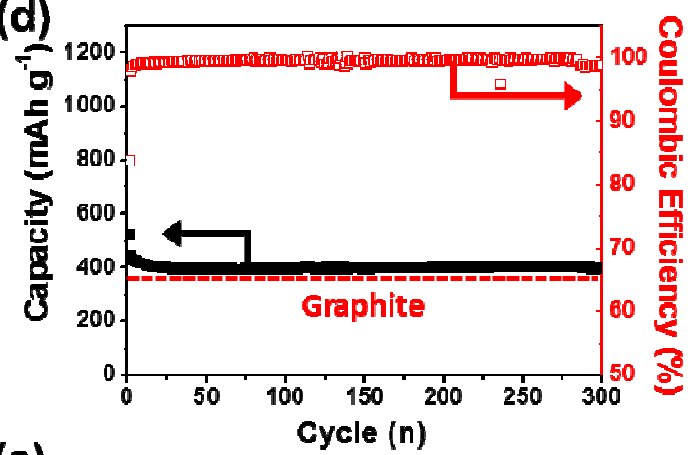

(e)
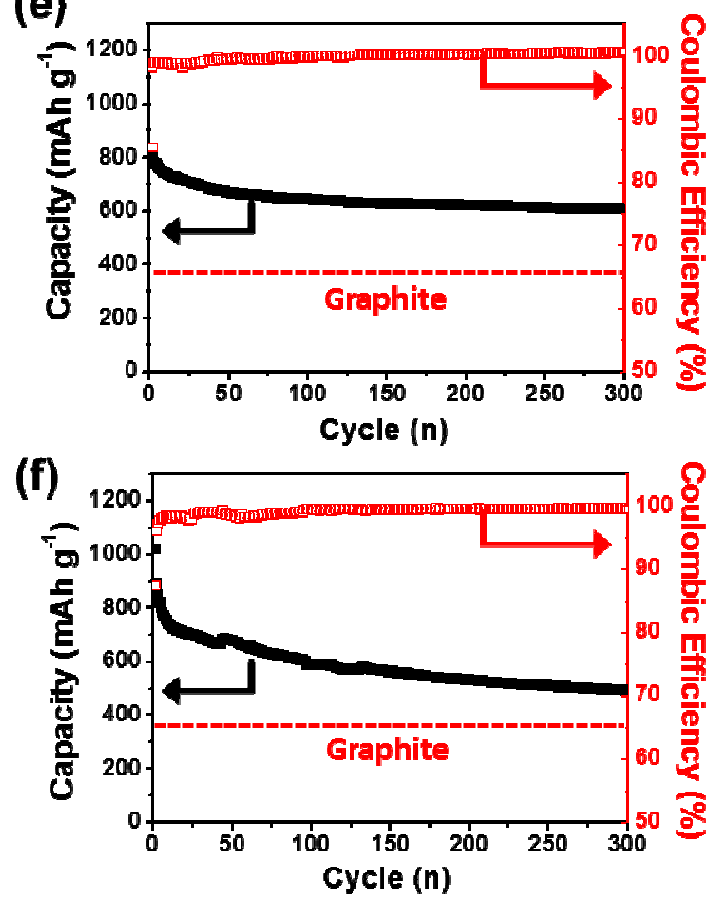

Figure S12. Electrochemical performances of Ge/HPC series composite electrodes with three different Ge contents (33\% for Ge/HPC-2 (a),(d), 50\% for Ge/HPC-1 (b),(e), 68\% for Ge/HPC-0.6 (c),(f)). (a-c) The first cycle voltage profiles of each electrode obtained at a rate of $\mathrm{C} / 20$ in the range of 0.01-3.0 V. (d-f) Cycle performances of three Ge/HPC series electrodes obtained at 0.5 rate in the range of $0.01-3.0 \mathrm{~V}$. 
(a)

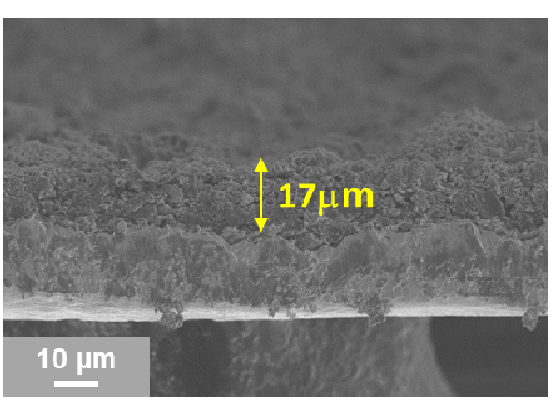

(b)

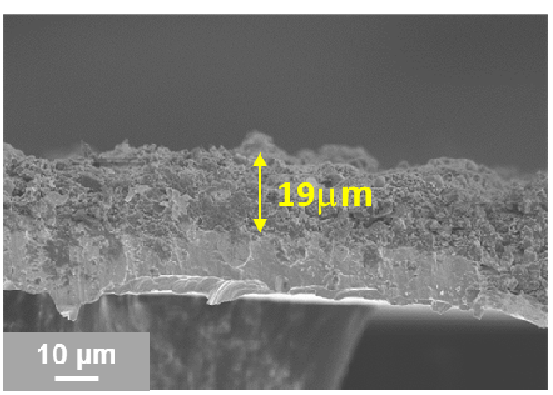

(c)

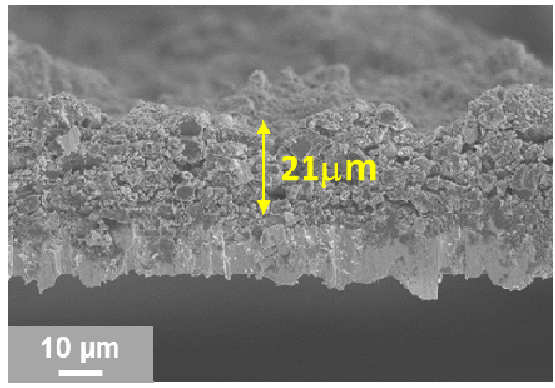

(d)

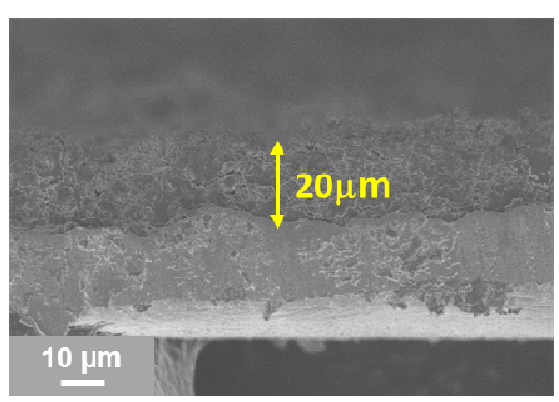

$(117 \%)$

(e)

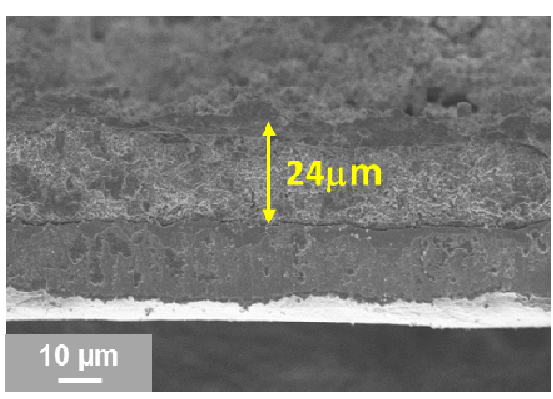

$(126 \%)$

(f)

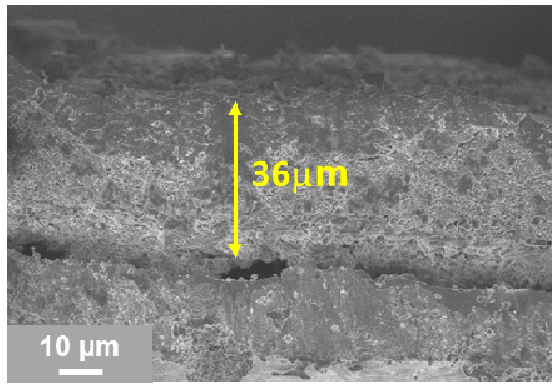

(171\%)

Figure S13. Cross-sectional SEM images of Ge/HPC-2 electrodes (a) before and after (d) $300^{\text {th }}$ cycle, Ge/HPC-1 electrodes (b) before and after (e) $300^{\text {th }}$ cycle, and Ge/HPC-0.6 electrodes (c) before and after (f) $300^{\text {th }}$ cycle. 